\title{
REVIEW
}

\section{The biology of activin: recent advances in structure, regulation and function}

\author{
Yin Xia and Alan L Schneyer ${ }^{1}$ \\ Program in Membrane Biology and Division of Nephrology, Center for Systems Biology, Massachusetts General Hospital, Harvard Medical School, Boston, \\ Massachusetts 02114, USA \\ ${ }^{1}$ Pioneer Valley Life Science Institute and University of Massachusetts-Amherst, 3601 Main Street, Springfield, Massachusetts 01107, USA \\ (Correspondence should be addressed to A L Schneyer; Email: alan.schneyer@bhs.org)
}

\begin{abstract}
Activin was discovered in the 1980 s as a gonadal protein that stimulated FSH release from pituitary gonadotropes and was thought of as a reproductive hormone. In the ensuing decades, many additional activities of activin were described and it was found to be produced in a wide variety of cell types at nearly all stages of development. Its signaling and actions are regulated intracellularly and by extracellular antagonists. Over the past 5 years, a number of important advances have been made that clarify our understanding of the structural basis for signaling and regulation, as well as the biological roles of

activin in stem cells, embryonic development and in adults. These include the crystallization of activin in complex with the activin type II receptor ActRIIB, or with the binding proteins follistatin and follistatin-like 3 , as well as identification of activin's roles in gonadal sex development, follicle development, luteolysis, $\beta$-cell proliferation and function in the islet, stem cell pluripotency and differentiation into different cell types and in immune cells. These advances are reviewed to provide perspective for future studies.

Journal of Endocrinology (2009) 202, 1-12
\end{abstract}

\section{Introduction}

Inhibin and activin were purified from gonadal fluids based on their ability to inhibit or stimulate (respectively) release of FSH from cultured pituitary gonadotropes. Following purification and molecular characterization, these hormones were identified as members of the TGF- $\beta$ superfamily, which now includes more than 40 ligands including TGF- $\beta$, inhibin, myostatin, and bone morphogenetic proteins (BMPs; Vale et al. 1988). Activin receptors were discovered later by functional cloning, revealing a type II receptor with serine/threonine kinase activity as the binding moiety (Mathews \& Vale 1993), which was later found to phosphorylate a type I receptor after ligand binding (Tsuchida et al. 2008). These discoveries along with the identification and characterization of extracellular activin antagonists such as follistatin (FST) and follistatinlike 3 (FSTL3; Welt et al. 2002), spurred a torrent of research activity into activin's biological roles in a wide spectrum of tissues and systems ranging from fate determination in embryos to homeostatic mechanisms in adults (reviewed in Mather et al. (1992), (1997), DePaolo (1997), Welt et al. (2002)). One of the continuing challenges in this field has been to decipher the in vivo activities of ligands that act primarily through autocrine and paracrine mechanisms where the value of the more classical endocrinological ablation and replacement paradigms is limited. Moreover, the requirement for activin during development has restricted the utilization of global knockout technology to address this issue. The more recent advent of conditional knockout technology, regulatable expression systems, and siRNA suppression technology is opening the door for more detailed investigations of activin's tissue-specific roles in adults.

The basics of activin signaling have been known for some time, although emerging details of cross-talk with other signaling pathways and an increasingly complex web of intracellular regulators adds new wrinkles at a regular pace (reviewed in Tsuchida et al. (2008)). This review will first focus on recent advances in our understanding of the structural basis for activin's interactions with its receptors and antagonists along with new information about how activin signaling and biosynthesis are regulated, after which we will summarize advances in our understanding of activin's biological roles, primarily in adults, published since our last comprehensive review (Welt et al. 2002). The role of activin in endocrine cancers, while important, was too vast to be included in this review. 


\section{Advances in activin structure-function relationships}

\section{Activin-receptor crystal structures}

The canonical activin signaling pathway involves an activin dimer binding to one of two type II receptors (ActRIIA or ActRIIB) in complex with activin's type I receptor ActRIB (a. k. a, activin receptor-like kinase $4, \mathrm{Alk} 4$ ), which ultimately leads to phosphorylation of the type I receptor. This receptor then phosphorylates the second messenger molecules Smad2 and Smad3 that, once activated, complex with a common Smad, Smad4. This complex then translocates to the nucleus where it activates gene transcription. Smad7 was identified as an inhibitory Smad that blocks phosphorylation of Smads 2 and 3 , thereby providing a short-loop negative feedback regulation for this signaling pathway (reviewed in Tsuchida et al. (2008)). Another level of regulation occurs extracellularly through soluble antagonists like FST and FSTL3 (Schneyer et al. 2001) or membrane bound modifiers like BMP and activin receptor membrane bound inhibitor (BAMBI) and Cripto (a GPI-anchored membrane protein, which inhibits activin signaling by forming an 'inert' complex with activin and ActRIIA; Onichtchouk et al. 1999, Kelber et al. 2008). Despite focused efforts; crystallization of activin alone was unsuccessful, suggesting that there may be considerable flexibility in how the two disulfide-linked subunits of activin are aligned. This was confirmed when activin A was crystallized in complex with ActRIIB extracellular domain (Thompson et al. 2003). In this structure, ActRIIB binds to the outer edges of the so-called finger regions on the activin dimer. Interestingly, the activin dimer in this model was tightly folded into a compact conformation unlike the extended configuration of other TGF- $\beta$ family members previously crystallized (Griffith et al. 1996, Hinck et al. 1996). Activin's flexibility and compact conformation was confirmed in a more highly resolved crystal structure with ActRIIB and suggested that this movement allowed binding sites for the type I receptor to be exposed once the type II receptor sites were occupied, thereby suggesting a mechanism for how the hexameric complex consisting of the activin dimer with two type II and two type I receptors is organized and activated (Greenwald et al. 2004). Support for this model comes from the remarkable achievement of crystallization of the ternary signaling complex comprised of a related ligand, BMP-2 and both receptor subtypes (Allendorph et al. 2006). These results showed that the ligand is the central coordinator of the complex with an absence of direct contacts between the receptors themselves (Allendorph et al. 2006). Moreover, they show that receptor specificity depends on specific unique residues arranged around a conserved hydrophobic core on type I receptors (Allendorph et al. 2006).

\section{Activin antagonist crystal structures}

FST, originally identified and isolated from both bovine and porcine follicular fluids on the basis of its inhibition of pituitary FSH secretion, is a monomeric glycosylated polypeptide chain that binds activin with high affinity and neutralizes most of its biological actions. FSTL3 was cloned from a B-cell leukemia line and it was originally named FSTrelated gene (FLRG) based upon primary sequence homology to FST. Subsequently, FSTL3 was also found to be a high-affinity activin binding protein (reviewed in Welt et al. (2002)).

As detailed previously, point mutagenesis and domain swapping studies were used to determine portions of the FST molecule that were critical for its neutralization of activin activity (Welt et al. 2002). FST is comprised largely of three successive 73-77 residue, 10-cysteine FST domains (FSDs), preceded by a 63-residue N-terminal domain (Welt et al. 2002). Residues on FSD2 and on the N-domain were found to be critical for activin binding (Sidis et al. 2001, 2005, Keutmann et al. 2004). Moreover, the N-domain, followed by at least two other FSDs were required for activin binding and neutralization (Keutmann et al. 2004). Rearrangement or substitution among the FSDs impaired or abolished activin binding, indicating that the number and order of FSDs were important for full activity (Keutmann et al. 2004). While these observations were instructive and consistent with binding to proposed receptor binding surfaces on activin, it was not until FST was crystallized with activin A that the significance of these observations were fully appreciated (Thompson et al. 2005). Two FST molecules envelop the activin dimer, covering a large percentage of the surface and completely blocking both type I and type II receptor binding sites (Thompson et al. 2005). Moreover, it appeared that the C-terminus of one FST molecule contacted the N-terminus of the other FST molecule as if to lock them in place (Thompson et al. 2005), suggesting a possible mechanism to account for the nearly irreversible kinetics identified much earlier (Schneyer et al. 1994, 1996). The FST-activin structure also confirmed the importance of FSD2 in contacting a large portion of the activin surface, thereby contributing substantially to the overall affinity of the interaction (Keutmann et al. 2004, Thompson et al. 2005).

More recently, FSTL3, which has one fewer FSD than FST, has been crystallized in complex with activin A revealing a similar overall structure with two FSTL3 molecules surrounding the activin dimer (Stamler et al. 2008). However, in this case, the $\mathrm{N}$-domain of FSTL3 contacts activin more extensively than in FST, enhancing its importance to activin binding and perhaps even compensating for the absence of a third FSD in FSTL3 (Stamler et al. 2008). The N-domain contacts may also influence ligand binding specificity (Stamler et al. 2008), thereby accounting for the previously determined difference in BMP binding between FST and FSTL3 (Sidis et al. 2006).

Myostatin is also a member of the TGF- $\beta$ superfamily closely related to activin, and FST can bind myostatin with relatively high-affinity, although not as high as activin itself (Sidis et al. 2006). Through site directed mutagenesis, it was found that mutations in FSD2, or replacement of FSD2 with FSD1 reduced activin binding but maintained myostatin 
binding activity, whereas mutations in FSD1 or replacement of FSD1 with another copy of FSD2 diminished myostatin binding but not activin binding (Schneyer et al. 2008). Thus, it was possible to create a myostatin-selective analog of FST that may be useful for designing new treatments for musclewasting disorders (Schneyer et al. 2008).

\section{Regulation of activin activity by antagonists}

Although it has been known for years that FST is produced as three isoforms resulting from alternative splicing and posttranslational proteolytic processing (Sugino et al. 1997), the relative activities of these different isoforms remained to be fully elucidated. As reviewed previously (Welt et al. 2002), the shorter FST288 isoform has a higher affinity for heparinsulfated proteoglycans located on the cell surface allowing FST288 to be concentrated at the outer surface of the plasma membrane and potentially prevent action of autocrine acting activin in addition to activin arriving from other cells or tissues (i.e. paracrine or endocrine acting activin). On the other hand, the longest isoform, FST315, was localized primarily in the circulation (Schneyer et al. 2004), consistent with its reduced affinity for heparin in the unliganded state. The intermediate isoform, FST303, was found primarily in gonadal extracts and fluids and thought to be derived by proteolytic processing of the C-terminal acidic tail (Sugino et al. 1997). FSTL3, which shares a number of structural features with FST, does not contain a heparin binding sequence and thus, does not bind cell-surface proteoglycans under normal conditions (Sidis et al. 2002). These biochemical distinctions suggested that the different FST isoforms and FSTL3 had distinct biological actions in vivo (Schneyer et al. 2001, Tortoriello et al. 2001, Sidis et al. 2002).

This hypothesis was tested by producing recombinant FST isoforms and assessing their binding kinetics for different TGF- $\beta$ ligands as well as their ability to inhibit biological activity when added as proteins (simulating paracrine/endocrine actions) or when transfected into cells (simulating autocrine actions). Activin binding kinetics were comparable between the FST isoforms and FSTL3 but cell-surface binding differed markedly (Sidis et al. 2006) as expected. Interestingly, inhibition of endogenous (e.g. autocrine) activin activity correlated closely with surface binding activity, whereas inhibition of exogenous (paracrine or endocrine) activin was not significantly different among the FST isoforms, consistent with their similar binding affinities (Sidis et al. 2006). Expression of FST315 as a membraneanchored protein transformed it from a soluble protein with weak antagonism to autocrine activin into an isoform that inhibited autocrine activin activity equal to that of the FST288 isoform (Sidis et al. 2006), supporting the concept that membrane localization via the heparin-binding sequence significantly increases inhibition of autocrine-acting activin. In addition, myostatin and BMP- 6 and -7 were inhibited by the FST isoforms, albeit to a lesser degree than that of activin, and this inhibition also correlated with their cell-surface binding (Sidis et al. 2006). These results support the hypothesis that differential cell-surface binding is the primary determinant of FST isoform biological activity and that these isoforms may have distinct bioactivities in vivo.

In support of the hypothesis, that FST isoforms have different in vivo actions, FST315 or FST288 cDNAs were expressed transgenically under control of the human promoter and crossed into the FST null mouse line (Lin et al. 2008), which had been previously demonstrated to be neonatally lethal (Matzuk et al. 1995c). While the FST288 expressing TG mice did not rescue this lethality, the FST315 expressing construct allowed mice to survive to adulthood with partial reversal of the skeletal abnormalities seen in FST null mice (Lin et al. 2008). However, these mice exhibited neonatal growth retardation, impaired tail growth and female infertility that may have resulted from failure of corpus luteum (CL) formation and a decline in ovarian follicle population (Lin et al. 2008). These results suggest that the FST288 isoform may be required for normal vascularization and ovarian function, whereas the FST315 isoform is sufficient for other regulatory actions that when absent, result in neonatal death (Lin et al. 2008), consistent with isoformspecific actions of FST in vivo. More detailed analysis awaits production of mice capable of producing individual FST isoforms from the endogenous FST locus.

Biochemical differences among the FST isoforms and FSTL3 also govern their biosynthesis and secretion. Using ${ }^{35} \mathrm{~S}$ pulse-chase labeling, FST315 was found to be synthesized and secreted the fastest while FST288 was secreted more slowly, with some FST288 remaining within the cell after extended incubation (Saito et al. 2005). FSTL3 was the slowest to be secreted with newly synthesized proteins being both secreted and transported to the nucleus (Saito et al. 2005). Interestingly, this nuclear FSTL3 was glycosylated but not to the same degree as secreted FSTL3, suggesting it may be derived from an endoplasmic reticulum (ER)-resident pool that is transported directly to the nucleus without first being secreted (Saito et al. 2005). These results indicate that both FST and FSTL3 may have both intracellular and extracellular roles that are governed to some degree by heparin-binding affinity (Saito et al. 2005).

\section{Regulation of activin synthesis}

Inhibin and activin share a common $\beta$-subunit with activin constituting a dimer of two $\beta$-subunits, whereas inhibin contains a related $\alpha$-subunit linked to the $\beta$-subunit (Vale et al. 1988). Thus, regulation of $\alpha$-subunit biosynthesis and dimerization with the $\beta$-subunit can alter activin biosynthesis in cells that synthesize both subunits such as ovarian granulosa cells. The mature portion of the $\alpha$-subunit is glycosylated and elimination of the carbohydrate chain at asp 268 inhibited inhibin secretion without altering activin secretion, while mutations of the $\beta$-subunit that induced its glycosylation also favored inhibin production (Antenos et al. 2007). These observations indicate that the degree of glycosylation determines the relative 
proportion of inhibin and activin produced in such cells (Antenos et al. 2007). Activin also stimulated production of both $\alpha$ - and $\beta$-subunit mRNA and protein, as well as the required proteolytic processing that removed mature hormone from the precursor portions of the subunit (Antenos et al. 2008). Interestingly, activin also stimulates furin biosynthesis through a smad2/3-dependent process, suggesting the presence of a short feedback loop to enhance secretion of mature activin and inhibin (Antenos et al. 2008).

\section{Advances in biological actions of activin in adults and embryonic stem cells}

\section{Activin and reproduction}

Biological roles for activin have been proposed in a number of reproductive organs including the gonads, uterus, and pituitary, where it regulates processes such as folliculogenesis, spermatogenesis, and pregnancy (reviewed in Welt et al. (2002)). Over the past several years, significant progress has been made in delineating the roles and mechanisms of activins in embryonic ovary development, follicle development, luteolysis, and testis development, as well as in regulation of FSH- $\beta$ gene transcription.

Activin and gonadal sex determination Emerging evidence suggests that FST and activins influence differentiation of the indifferent gonad as well as the early stages of folliculogenesis. Embryonic XX, but not XY gonads express FST, with mRNA becoming detectable in the E11.5 XX mouse gonad (Menke \& Page 2002, Yao et al. 2004). In support of a role for FST in regulating development of female gonads, FST null XX gonads develop a coelomic vessel, the rudiment of the testis-specific vasculature structure that organizes and patterns the developing testis, suggesting that FST possesses an anti-testis function (Yao et al. 2004). In the mouse XX gonad on E12.5, $\beta$-B but not $\beta$-A subunit mRNA is expressed, which is in contrast to the expression of both $\beta-B$ and $\beta-A$ subunit mRNA in XY gonads. Interestingly, in FST and $\beta-\mathrm{B}$ subunit double knockout embryos, vasculature development in $\mathrm{XX}$ gonads was reversed from the FST null phenotype to wild type (i.e. female) while local application of activin B induced ectopic formation of coelomic vessel in cultured XX gonads, and $\beta-\mathrm{B}$ knockout XY gonads exhibited defects in coelomic vessel formation (Yao et al. 2004). These results suggest that activin $\mathrm{B}$ induces the formation of the coelomic vessel in both $\mathrm{XY}$ and XX gonads, but this action is normally inhibited by FST in the XX gonad (Yao et al. 2004, 2006a). Although the role of activin and FST in gonadal differentiation has not been established in other species, Xia et al. (2008b), found that FST concentrations were higher in fetal blood and allantoic fluids from female fetuses compared with male fetuses during early pregnancy in sheep, suggesting that FST may also have important roles in sexual development in non-rodent species.
Activin and follicle development Initial follicle pool formation is critical for normal fertility in adult-female mammals. Studies on developing mouse and human ovaries suggest that activins are involved in regulation of germ cell proliferation during the developmental period leading up to primordial follicle formation, which occurs at $24 \mathrm{~h}$ after birth in the mouse and 21 weeks of gestation in the human (Martins da Silva et al. 2004, Bristol-Gould et al. 2006). In mouse ovaries from postnatal days 0 and 4 , activin $\beta$-A and $\beta-B$ subunits, and activin receptors ActRIIA, ActRIIB, and ALK4 are expressed in both somatic cells and oocytes, suggesting that neonatal mouse ovaries produce activin and are activinresponsive (Bristol-Gould et al. 2006). Administration of activin A to female pups from birth to day 4 increased germ cell and granulosa-cell proliferation, as well as the number of primordial follicles formed from the germ cell nests, without any effect on apoptosis in these cells (Bristol-Gould et al. 2006). Activin subunits, $\beta-A$ and $\beta-B$, the receptors ActRIIA and ActRIIB, and downstream effectors Smad2/3 are also expressed in human fetal ovaries at 14-19 weeks of gestation (Martins da Silva et al. 2004, Coutts et al. 2008). Interestingly, $\beta$-A subunit mRNA expression increased twofold from 14 to 19 weeks of gestation, and treatment of human ovaries between 14 and 17 weeks of gestation with activin A dramatically increased oogonial proliferation (Martins da Silva et al. 2004). These results suggest that activin signaling may play an important role in determining the size of the primordial follicle pool in humans as well as mice. Since this is the total endowment of follicles for the female's lifetime, these results also suggest that activin signaling may be important in premature ovarian failure where functional follicles are prematurely exhausted (Anasti 1998).

Activins and FSTs were originally isolated from follicular fluids and these proteins are predominantly expressed in granulosa cells. Multiple roles have been proposed for granulosa cell activin including regulation of proliferation, differentiation, and steroidogenesis (reviewed in Welt et al. (2002)). More recently discovered actions for activin include synergistic actions of activin with FSH to promote G1/S transition and cell proliferation in rat primary granulosa cells, a process accompanied by induction of $\mathrm{CycD} 2$ expression and phosphorylation of retinoblastoma protein (Ogawa et al. 2003, Park et al. 2005). In addition, induction of $\mathrm{CycD} 2$ by activin/FSH involved activation of phosphatidylinositol 3-kinase and Akt pathways (Park et al. 2005). Activin was also shown to increase the $\operatorname{ER} \alpha$ and $\beta$ in mouse granulosa cells both in vitro and in vivo suggesting that the activin and estrogen signaling pathways intersect to regulate granulosa cell activity and follicle development (Kipp et al. 2007).

Genetic elimination of activin $\beta-A$ resulted in mouse pups that died within $24 \mathrm{~h}$ of birth with craniofacial and other defects (Matzuk et al. 1995b) while activin $\beta$-B deficient mice survived to become fertile adults but offspring of $\beta \mathrm{B}$-deficient females died perinatally, perhaps from insufficient lactation 
(Vassalli et al. 1994). To explore the role of activin A in ovarian follicle development, granulosa cell-specific conditional $\beta$-A subunit knockout mice were created, resulting in subfertility with enhanced CL survival and accumulation within the ovary (Pangas et al. 2007). These results, in combination with the observation that replacement of mature $\beta$-A with mature $\beta-B$ results in subfertility (Brown et al. 2000), suggest that both activin $A$ and $B$ have important roles within the ovary with activin A being functionally dominant over activin B (Pangas et al. 2007).

Transgenic overexpression of FST in ovaries led to a blockade in follicular development before antral follicle formation suggesting FST had important roles in ovarian physiology (Guo et al. 1998), perhaps through regulation of activin action. Consistent with this observation, granulosa cell-specific overexpression of FSTL3, the related activin antagonist, resulted in fewer antral follicles in adult females (Xia et al. 2004), while deletion of FSTL3 resulted in mild subfertility in females and increased testis size in males (Mukherjee et al. 2007). Since global FST null mice died just after birth and are therefore not useful for analyzing adult FST roles, Jorgez et al. (2003) created a conditional $f_{s t}$ allele and used these mice to delete FST production from ovarian follicles. This led to decreased antral follicle number in 3 -month old mice, as well as decreased litter number and size (Jorgez et al. 2003), suggesting that optimized signaling of activins, and/or other TGF- $\beta$ family members bound by FST and FSTL3 (e.g. BMP-6 and -7, see (Sidis et al. 2006, Schneyer et al. 2008)) are required to maintain normal development from secondary to antral follicles (Jorgez et al. 2003). An additional phenotype developed as the females matured with accelerated loss of follicles, early ovarian senescence and elevated gonadotropins, (Jorgez et al. 2003) similar to the human infertility condition known as premature ovarian failure (Anasti 1998).

Several FST isoforms were recently identified in ovine (Xia et al. 2008a) and bovine gonads (Glister et al. 2006) by western blotting. The relative amounts of these FST isoforms varied during follicle maturation although the total FST concentration in both ovine and bovine follicular fluids declined with follicle development, suggesting that regulation of activin action by intrafollicular FST changes as follicles mature (Glister et al. 2006, Xia et al. 2008a). In fact, FST isoform distribution and biological role appears to depend on biochemical features distinct within the FST isoforms themselves such as the ability to bind to heparin sulfated proteoglycans on the surface of cells (Sidis et al. 2006). Thus, the longest isoform that has little cell-surface binding ability is largely found in serum (Schneyer et al. 2004) while follicular fluid appears to contain predominantly the intermediate sized isoform, FST303 (Sugino et al. 1993). This model is further supported by a mouse model where a human FST315 minigene was expressed transgenically under the direction of the human FST promoter and then crossed with the FST null mouse model described above (Lin et al. 2008). These FST315/303-expressing mice survived to adulthood but females were subfertile with reduced numbers of primordial, primary, and secondary follicles, and no antral follicles and CL (Lin et al. 2008).

Activin and luteolysis Using cocultures of cells isolated from human CL, Myers et al. $(2007,2008)$ demonstrated that activin derived from luteinized granulosa cells increased expression of matrix metalloproteinase-2 (MMP-2) by fibroblast-like cells, and that this activity was inhibited by FST. MMPs are key proteolytic enzymes involved in the degradation of the extracellular matrix, and MMP-2 is an important luteolytic agent during the demise of CL (Myers et al. 2007), thereby suggesting that activin may play an active role in regression of CL survival. This notion is supported by analyses of ovary-specific deletion of activins in mice in which the ovaries displayed progressive accumulation of CLs and the absence of CL regression (Pangas et al. 2007). Additional support for this concept comes from the observation that FST mRNA expression is dramatically reduced in regressing CLs compared with newly formed CLs in rats which created a low FST/high-activin environment (Erickson \& Shimasaki 2003). On the other hand, FST release from the ovary increased at luteolysis in sheep, which may be another mechanism to create a low FST environment through FST secretion rather than keeping the FST in follicular fluid (Xia et al. 2008b).

Activin and testicular function Smaller testes and reduced fertility were observed in mice when activin signaling was down regulated by inactivation of ActRIIA (Matzuk et al. 1995a), or when FST (Guo et al. 1998) or FSTL3 (Xia et al. 2004) were transgenically overexpressed. Moreover, in the FSTL3 transgenic mice, reduced testis weight was observed as early as postnatal day 7 (Xia et al. 2004). The mechanism whereby activin might control testis size was suggested in early studies showing that activin can directly promote Sertoli cell proliferation in culture (Mather et al. 1990), and supported by more recent observations that the primary source for activin-A in the testis was peritubular myoid cells which acts in a paracrine fashion to promote Sertoli cell proliferation only when the Sertoli cells were obtained between neonatal days 3 and 9 (Buzzard et al. 2003). Taken together, these results support the concept that disrupted activin signaling may limit Sertoli cell proliferation in a critical developmental window which persists as reduced testis weight in adults because the number of Sertoli cells established during this proliferative phase in neonates constitutes an upper limit to spermatogenic output in adults (Sharpe et al. 2003). Therefore, activin signaling during early-testicular development appears to determine ultimate testis size and function in adults, and may be regulated by activin antagonists including FSTL3 (Xia et al. 2004) and FST (Guo et al. 1998).

Activin actions in the pituitary Activin was originally purified on the basis of its ability to stimulate FSH release from pituitary gonadotropes (Vale et al. 1988) and it 
was subsequently shown that activin is a critical regulator of FSH- $\beta$ biosynthesis (Weiss et al. 1992). More recent studies have shown that Smad3 is the principal regulator of activininduced FSH- $\beta$ subunit transcription, while Smad2 may be more involved in regulation of basal FSH- $\beta$ transcription in murine immortalized L $\beta$ T2 gonadotrope cells (Suszko et al. 2003, 2005, 2008, Bernard 2004, Gregory \& Kaiser 2004, Lamba et al. 2006). This functional difference between Smad2 and Smad3 appears to be attributed to the second of the two loops in the Smad2 MH1 domain, which is thought to bury a $\beta$-hairpin loop structure thereby preventing Smad2 from directly binding its cognate DNA (Suszko et al. 2005). In addition, activin stimulation of FSH- $\beta$ gene transcription involves Smad3 partners, including Pitx2c (a pituitary-specific transcription factor; Suszko et al. 2008) and TALE homeodomain proteins Pbx1 and Prep1 (Bailey et al. 2004).

FSH biosynthesis is also regulated at the transcriptional level by gonadal steroids, glucocorticoids and $\mathrm{GnRH}$, and these actions are modulated by activin signaling. For example, androgen and activin synergistically stimulate FSH- $\beta$ transcription, and the stimulation by androgen or activin alone is dependent on the presence of an intact Smad binding element or androgen response element (respectively) within the FSH$\beta$ promoter (Spady et al. 2004, Thackray \& Mellon 2008). Glucocorticoids and activin also synergistically activate FSH$\beta$ transcription and this synergy occurs at the level of the FSH- $\beta$ promoter (McGillivray et al. 2007). The role of $\mathrm{GnRH}$ in regulation of activin induced FSH- $\beta$ transcription is more complex, because chronic administration (20-24 h) inhibits activin action (Shafiee-Kermani et al. 2007), whereas acute (4-6 h) GnRH synergistically enhances it (Gregory et al. 2004) and the interaction can also be species specific, making interpretation of heterologous reporter experiments challenging (Lamba et al. 2008, Wang et al. 2008b).

Activin also modulates transcription of $\mathrm{LH}-\beta$ subunit and GnRH receptor mRNA (Cherrington et al. 2005, Coss et al. $2005)$ as well as a number of other genes in L $\beta T 2$ cells including inhbb, inha, gdf9, and the $17 \beta-H S D$ gene (Zhang et al. 2006). Activin also regulates the number of $\mathrm{GnRH}$ receptors and hence, response to GnRH (Gregory \& Kaiser 2004). Thus, in addition to direct regulation of FSH- $\beta$ biosynthesis, activin has important actions in modulating $\mathrm{LH}-\beta$ biosynthesis and release through regulation of $\mathrm{GnRH}$ action, together supporting a major role for activin in modulating neuroendocrine reproductive control.

\section{Activin and glucose metabolism}

Roles for activins and related members of the TGF- $\beta$ family in regulating pancreatic $\beta$-cell number and/or function have been proposed for some time, and more recent results have refined those concepts, although the precise ligands and their actions in the pancreas remain to be definitively demonstrated. For example, activin can enhance glucose stimulated insulin secretion in $\beta$-cells from rats and humans in culture (Totsuka et al. 1988, Verspohl et al. 1993, Furukawa et al.
1995, Florio et al. 2000), and $\beta$-cell proliferation is enhanced with activin treatment (Brun et al. 2004, Li et al. 2004). In addition, all components of the activin/TGF- $\beta$ signaling pathway have been identified in $\beta$-cells, including the ligands themselves, receptors, second messengers, and antagonists (Ogawa et al. 1993, Wada et al. 1996, Yamaoka et al. 1998). However, from these studies alone it was not possible to determine if activin or related ligands had physiological roles regulating $\beta$-cell proliferation or function in vivo.

Yamaoka et al. (1998) demonstrated that transgenic overexpression of a dominant negative type II activin receptor in islets resulted in islet hypoplasia, reduced insulin content and impaired glucose tolerance, although the ratios of $\boldsymbol{\alpha}$ - and $\beta$-cells was not altered. Although this study implicated activin in regulating $\beta$-cell proliferation, maturation, and possibly functions it was not possible in this model to differentiate between developmental effects and regulation of $\beta$-cells in adults. To circumvent this limitation, Smart et al. (2006) used a conditional transgenic strategy to overexpress Smad7 in $\beta$-cells. Smad7 is known as an inhibitory Smad which, unlike the signaling Smads, inhibits signaling in the activin/TGF- $\beta$ pathway (Bhushan et al. 1998). Expression of Smad7 was inhibited in embryonic and neonatal mice by treating with doxycycline (Dox) and then induced in adult mice by removal of Dox, resulting in inhibition of the Smad2/Smad3 signaling pathway of activin and TGF- $\beta$ (Smart et al. 2006). In these mice, $\beta$-cell gene expression, insulin content, serum insulin, and glucose tolerance were all reduced compared with controls, and these effects were reversible with Dox administration (Smart et al. 2006). Thus, activin and/or related ligands have important roles in regulating $\beta$-cell number and function in rodents.

Further support for a role for activin in regulating $\beta$-cell proliferation and function was reported by Mukherjee et al. (2007) when they created a global FSTL3 null mouse. Among other metabolic alterations, islets were nearly twice as large and contained mostly $\beta$-cells, insulin levels were slightly increased, and both glucose tolerance and insulin sensitivity, as assessed by glucose and insulin tolerance tests respectively, were enhanced. These observations suggest that removal of a natural activin antagonist resulted in increased activin bioactivity and increased $\beta$-cell mass and function (Mukherjee et al. 2007).

Although in vitro biological studies usually find nearly identical actions of activin A and B (Welt et al. 2002), activin $\mathrm{B}$ was shown to also use Alk7 as an alternative type I receptor (Tsuchida et al. 2004), suggesting activins A and B might have distinct actions in vivo. This concept is supported by the different phenotypes observed with activin A and B knockout mice (Matzuk et al. 1995b). In addition, Bertolino et al. (2008) found that Alk7 (and presumably, its ligand activin B) is a negative regulator of $\beta$-cell function, a finding in opposition to the reported stimulatory actions of activin A described above. Alk7 KO mice developed progressive hyperinsulinemia, reduced insulin sensitivity and impaired glucose tolerance. It appears that activin $\mathrm{B}$ acts by reducing 
glucose-stimulated calcium influx (Bertolino et al. 2008). Moreover, activin B KO mice have hyperinsulinemia consistent with activin $\mathrm{B}$ negatively regulating insulin production and secretion in $\beta$-cells (Bertolino et al. 2008).

Experimental reduction of $\beta$-cell mass has been shown to induce proliferation of ductal tissues within remaining pancreas and differentiation of insulin-producing cells to compensate for lost islets in a process known as neogenesis (Bonner-Weir 1994). More recently, it was found that activin expression is increased in ductal tissues and co-localized with the cytokeratin maker for ductal cells after reduction of $\beta$-cell mass with streptozotocin or partial pancreatectomy (Zhang et al. 2002). Activin was also found to increase proliferation of rat ductal cells in vitro, as well as to induce their differentiation into insulin producing cells expressing PDX-1, Ngn-3, and other genetic markers of $\beta$-cells (Park et al. 2007). Glucosestimulated insulin secretion was also enhanced in these cells, and when transplanted, were able to reverse streptozotocininduced diabetes in rats (Park et al. 2007). These observations suggest that activin may also influence replication and differentiation of islet-cell progenitors located in ductal epithelium.

While activin's role in regulating $\beta$-cell proliferation and function appears to be important for maintaining normal glucose metabolism in adults, its role with other islet cell types remains relatively unexplored. However, activin was shown to decrease glucagon gene expression in $\boldsymbol{\alpha}$-cell lines and in human islets in culture and inhibit proliferation of $\boldsymbol{\alpha}$-cell lines in culture by inhibiting synthesis of Arx (Mamin \& Philippe 2006). These results suggest that activin A may have opposite roles in regulating $\alpha$ - and $\beta$-cells in adults in ways that enhance glucose uptake and decrease its synthesis, actions favorable to relieving symptoms of diabetes.

\section{Activin and stem cell differentiation}

Embryonic stem cells, both mouse and human, were first cultured on mouse feeder cell layers to maintain pluripotency during expansion. The need for completely defined culture conditions for use in human embryonic stem cell (hESC) therapies drove efforts to identify culture medium components that facilitated hESC proliferation while maintaining pluripotency. Activin and other TGF- $\beta$ family members signaling through Smads 2 and 3 were found to maintain hESC pluripotency and self-renewal (Beattie et al. 2005, James et al. 2005, Vallier et al. 2005) and that blocking activin signaling resulted in hESC differentiation (Vallier et al. 2005, Wu et al. 2008). Moreover, activin often interacts with other growth factors like fibroblast growth factor (FGF) to maintain pluripotency (Vallier et al. 2005, Xiao et al. 2006). The mechanism for these activities appears to involve inhibition of BMP signaling by the interaction of activin and FGF pathways (Willems \& Leyns 2008), thereby sustaining expression of such stem cell genes as Nanog, Oct4 and Sox2 through Smad binding to the Nanog promoter ( $\mathrm{Xu}$ et al. 2008). It was additionally reported that this activin and nodal mechanism seems to be universal among mammals since it maintains pluripotency of epiblast stem cells from mice and rats, demonstrating that previously observed differences between mouse and hESCs could be overcome and that both could be maintained in the pluripotent state with activin or nodal treatment (Brons et al. 2007, Ogawa et al. 2007).

Upon removal or inhibition of activin signaling, hESC differentiation ensues, either in embryoid bodies or as monolayers. Another goal of ESC research is to direct hESC differentiation into distinct pathways. Recapitulating normal embryonic development, where activin is important in endoderm/mesoderm formation and patterning (Tremblay et al. 2000, Kumar et al. 2003), the reapplication of activin induces hESCs to form endoderm (Yao et al. 2006b, Funa et al. 2008, Sumi et al. 2008) and even differentiate into distinct cell types such as insulin producing $\beta$-cells (Shi et al. 2005, Frandsen et al. 2007, Jiang et al. 2007, Phillips et al. 2007, Jafary et al. 2008), hepatocytes (Hay et al. 2008), parathyroid-like tissue (Bingham et al. 2008), neuroectoderm (Smith et al. 2008), blood cells (Nostro et al. 2008, Pearson et al. 2008), and cardiomyocytes (Kitamura et al. 2007), perhaps through modulation of other important developmental signaling systems such as sonic hedgehog (Mfopou et al. 2007, Mfopou \& Bouwens 2008). Thus, activin has critical activities in regulating hESC pluripotency, and then differentiation into endoderm and its tissue derivatives that appear to be useful for directly ESC differentiation in vitro.

\section{Activin and immune response}

The importance of TGF- $\beta$ family members in immune system function was first demonstrated by the targeted disruption of TGF- $\beta 1$ in mice, which resulted in a severe multifocal inflammation (Shull et al. 1992). Subsequent studies revealed that activins (reviewed in Jones et al. (2004b)) and BMPs (Gould et al. 2002, Lee et al. 2003, Hagen et al. 2007) are also important regulators of inflammatory responses in various cell types and organs.

Activin expression has been detected in many immune cells including monocytes (Eramaa et al. 1992, Abe et al. 2002), macrophages (Ebert et al. 2007), dendritic cells (Robson et al. 2008), T and B lymphocytes (Ogawa et al. 2006, 2008), and mast cells (Cho et al. 2003, Funaba et al. 2003), and its expression increases when these cells are activated by immune stimuli and toll-like receptor agonists. For example, microglial cells (quiescent central nervous system resident macrophagelike cells) and peritoneal macrophages released activin A and its binding protein FST after treatment with TLR2 agonist Pam3Cys, TLR4 agonist LPS, or TLR9 ligand CpG (cytosin-guanosin oligodesoxynucleotide 1668; Michel et al. 2003b, Ebert et al. 2007).

Blood dendritic cells and monocyte-derived dendritic cells express activin mRNA, and secretion of activin A protein was dramatically increased in the presence of Escherichia coli, or CD40 ligand (CD40L), or various TLR ligands (Robson et al. 2008). Secreted activin A then negatively regulated 
production of cytokines (IL-6, IL-12p70, TNF- $\alpha$, and IL-10) and chemokines (IL-8, IP-10 RANTES, and MCP-1) induced by the CD40L/CD40 pathway in an autocrine/ paracrine manner (Robson et al. 2008). These inhibitory functions of activin released by dendritic cells may play an important role in preventing uncontrolled release of cytokine/chemokine and recruitment of immune effectors within the local microenvironment (Robson et al. 2008). Activin was also expressed in activated $\mathrm{CD} 4{ }^{+} \mathrm{CD} 25^{-} \mathrm{T}$ cells in the spleen and promoted differentiation of macrophages into alternatively (M-2 phenotype) activated macrophages (Ogawa et al. 2006). In addition, activin treatment inhibited IFN- $\gamma$ - or LPS-induced $\mathrm{NO}_{2}$ production, and suppressed LPS-induced pinocytosis and expression of TLR 4 in mouse macrophages (Zhang et al. 2005, Ogawa et al. 2006, Wang et al. 2008a). Through direct action on resting B cells, activin A enhanced $\operatorname{IgG}$ and $\operatorname{IgE}$ production (Ogawa et al. 2008). These results indicate that activin is produced by a variety of cell types in the immune system and has regulatory actions on many of them, suggesting an intricate autocrine/paracrine system whereby activin modulates certain immune responses.

In addition to upregulation of activin expression in activated immune cells, activin expression is also stimulated by inflammatory mediators including LPS in endothelial cells (Wilson et al. 2006) and Sertoli cells (Okuma et al. 2005, Riccioli et al. 2006, Jones et al. 2007). Furthermore, increased activin A expression was also found in many other cell types in inflamed or wounded tissues (Hubner et al. 1996, Ota et al. 2003, Fumagalli et al. 2007, Kaitu'u-Lino et al. 2008). Thus, activin appears to play an important role both in immune response and immune reactions during wound repair, as well as perhaps influencing wound repair directly (Hubner et al. 1999).

As a result of these immune system actions, elevated systemic activin A concentrations were found in the serum of patients with septicemia or angina (Michel et al. 2003a, Smith et al. 2004). In fact, a rapid increase in circulating activin A, peaking within $1 \mathrm{~h}$, was observed after LPS administration to sheep or mice, a response which preceded the systemic release of TNF- $\alpha$, IL-6, IL-1 $\beta$, and FST (Jones et al. 2004a, 2007). Blockade of activin action with FST treatment altered the profiles of TNF- $\alpha$, IL- 6 , and IL- $1 \beta$ after LPS stimulation and enhanced survival from a lethal LPS dose, suggesting that activin modulates the release of other key proinflammatory cytokines (Jones et al. 2007). These results demonstrate that activin plays a crucial role in the inflammatory response and that blocking its actions may have therapeutic potential in treatment modalities for acute inflammatory disorders (Jones et al. 2007).

\section{Summary}

Over the past 5 years, substantial progress was made in elucidating the biological actions of activin in adult animals, taking advantage of novel techniques that allow regulation of the timing of genetic alterations in mice as models for human disease. The important actions so far enumerated indicate that activin has many important homeostatic functions in adult humans and is thus likely also to contribute to disease in those individuals where activin expression or bioactivity is altered. While no associations with human disease have yet been identified for activins A or B in genome wide association studies, FST and/or FSTL3 levels are altered, for example, in heart disease (Lara-Pezzi et al. 2008), suggesting that such associations might be uncovered in the near future as more individuals are genotyped. It is therefore likely that new actions of activin, as well as its involvement in disease, will be identified with additional research and that pharmaceuticals based on modulation of activin signaling having therapeutic value may be discovered in the next few years.

\section{Declaration of interest}

Authors have no conflicts to declare.

\section{Funding}

This work was supported in part by the NIH (R01DK075058) to A L S.

\section{References}

Abe M, Shintani Y, Eto Y, Harada K, Kosaka M \& Matsumoto T 2002 Potent induction of activin A secretion from monocytes and bone marrow stromal fibroblasts by cognate interaction with activated T cells. Journal of Leukocyte Biology 72 347-352.

Allendorph GP, Vale WW \& Choe S 2006 Structure of the ternary signaling complex of a TGF-beta superfamily member. PNAS 103 7643-7648.

Anasti JN 1998 Premature ovarian failure: an update. Fertility and Sterility $\mathbf{7 0}$ $1-15$.

Antenos M, Stemler M, Boime I \& Woodruff TK 2007 N-linked oligosaccharides direct the differential assembly and secretion of inhibin alpha- and betaA-subunit dimers. Molecular Endocrinology 21 1670-1684.

Antenos M, Zhu J, Jetly NM \& Woodruff TK 2008 An activin/furin regulatory loop modulates the processing and secretion of inhibin $\boldsymbol{\alpha}$ - and $\beta \mathrm{B}$-subunit dimers in pituitary gonadotrope cells. Journal of Biological Chemistry 283 33059-33068.

Bailey JS, Rave-Harel N, McGillivray SM, Coss D \& Mellon PL 2004 Activin regulation of the follicle-stimulating hormone beta-subunit gene involves Smads and the TALE homeodomain proteins Pbx1 and Prep1. Molecular Endocrinology 18 1158-1170.

Beattie GM, Lopez AD, Bucay N, Hinton A, Firpo MT, King CC \& Hayek A 2005 Activin A maintains pluripotency of human embryonic stem cells in the absence of feeder layers. Stem Cells 23 489-495.

Bernard DJ 2004 Both SMAD2 and SMAD3 mediate activin-stimulated expression of the follicle-stimulating hormone beta subunit in mouse gonadotrope cells. Molecular Endocrinology 18 606-623.

Bertolino P, Holmberg R, Reissmann E, Andersson O, Berggren PO \& Ibáñez CF 2008 Activin B receptor ALK7 is a negative regulator of pancreatic beta-cell function. PNAS 105 7246-7251.

Bhushan A, Chen Y \& Vale W 1998 Smad7 inhibits mesoderm formation and promotes neural cell fate in Xenopus embryos. Developmental Biology 200 260-268.

Bingham EL, Cheng SP, Ignatoski KW \& Doherty GM 2008 Differentiation of hES cells to a parathyroid-like phenotype. Stem Cells and Development (in press: DOI 10.1089/3cd-2008.0337). 
Bonner-Weir S 1994 Regulation of pancreatic beta-cell mass in vivo. Recent Progress in Hormone Research 49 91-104.

Bristol-Gould S, Kreeger P, Selkirk C, Kilen S, Cook R, Kipp J, Shea LD, Mayo KE \& Woodruff TK 2006 Postnatal regulation of germ cells by activin: the establishment of the initial follicle pool. Developmental Biology $2980132-148$.

Brons IG, Smithers LE, Trotter MW, Rugg-Gunn P, Sun B, Chuva de Sousa Lopes SM, Howlett SK, Clarkson A, Ahrlund-Richter L, Pedersen RA et al. 2007 Derivation of pluripotent epiblast stem cells from mammalian embryos. Nature 448 191-195.

Brown CW, Houston-Hawkins DE, Woodruff TK \& Matzuk MM 2000 Insertion of Inhbb into the Inhba locus rescues the Inhba-null phenotype and reveals new activin functions. Nature Genetics 25 453-457.

Brun T, Franklin I, St-Onge L, Biason-Lauber A, Schoenle EJ, Wollheim CB \& Gauthier BR 2004 The diabetes-linked transcription factor PAX4 promotes $\beta$-cell proliferation and survival in rat and human islets. Journal of Cell Biology 167 1123-1135.

Buzzard JJ, Farnworth PG, de Kretser DM, O'Connor AE, Wreford NG \& Morrison JR 2003 Proliferative phase sertoli cells display a developmentally regulated response to activin in vitro. Endocrinology 144 474-483.

Cherrington BD, Farmerie TA, Lents CA, Cantlon JD, Roberson MS \& Clay CM 2005 Activin responsiveness of the murine gonadotropinreleasing hormone receptor gene is mediated by a composite enhancer containing spatially distinct regulatory elements. Molecular Endocrinology 19 898-912.

Cho SH, Yao Z, Wang SW, Alban RF, Barbers RG, French SW \& Oh CK 2003 Regulation of activin A expression in mast cells and asthma: its effect on the proliferation of human airway smooth muscle cells. Journal of Immunology 170 4045-4052.

Coss D, Thackray VG, Deng CX \& Mellon PL 2005 Activin regulates luteinizing hormone beta-subunit gene expression through Smad-binding and homeobox elements. Molecular Endocrinology 19 2610-2623.

Coutts SM, Childs AJ, Fulton N, Collins C, Bayne RAL, McNeilly AS \& Anderson RA 2008 Activin signals via SMAD2/3 between germ and somatic cells in the human fetal ovary and regulates kit ligand expression. Developmental Biology 314 189-199.

DePaolo LV 1997 Inhibins, activins, and follistatins: the saga continues. Proceedings of the Society for Experimental Biology and Medicine 214 328-339.

Ebert S, Zeretzke M, Nau R \& Michel U 2007 Microglial cells and peritoneal macrophages release activin A upon stimulation with Toll-like receptor agonists. Neuroscience Letters 413 241-244.

Eramaa M, Hurme M, Stenman UH \& Ritvos O 1992 Activin A/erythroid differentiation factor is induced during human monocyte activation. Journal of Experimental Medicine 176 1449-1452.

Erickson GF \& Shimasaki S 2003 The spatiotemporal expression pattern of the bone morphogenetic protein family in rat ovary cell types during the estrous cycle. Reproductive Biology and Endocrinology 19.

Florio P, Luisi S, Marchetti P, Lupi R, Cobellis L, Falaschi C, Sugino H, Navalesi R, Genazzani AR \& Petraglia F 2000 Activin A stimulates insulin secretion in cultured human pancreatic islets. Journal of Endocrinological Investigation 23 231-234.

Frandsen U, Porneki AD, Floridon C, Abdallah BM \& Kassem M 2007 Activin B mediated induction of $\mathrm{Pdx} 1$ in human embryonic stem cell derived embryoid bodies. Biochemical and Biophysical Research Communications $362568-574$.

Fumagalli M, Musso T, Vermi W, Scutera S, Daniele R, Alotto D, Cambieri I, Ostorero A, Gentili F, Caposio P et al. 2007 Imbalance between activin A and follistatin drives postburn hypertrophic scar formation in human skin. Experimental Dermatology 16 600-610.

Funa NS, Saldeen J, Akerblom B \& Welsh M 2008 Interdependent fibroblast growth factor and activin A signaling promotes the expression of endodermal genes in differentiating mouse embryonic stem cells expressing Src homology 2-domain inactive Shb. Differentiation 76 443-453.

Funaba M, Ikeda T, Ogawa K, Murakami M \& Abe M 2003 Role of activin A in murine mast cells: modulation of cell growth, differentiation, and migration. Journal of Leukocyte Biology 73 793-801.

Furukawa M, Nobusawa R, Shibata H, Eto Y \& Kojima I 1995 Initiation of insulin secretion in glucose-free medium by activin A. Molecular and Cellular Endocrinology 113 83-87.
Glister C, Groome NP \& Knight PG 2006 Bovine follicle development is associated with divergent changes in activin-A, inhibin-A and follistatin and the relative abundance of different follistatin isoforms in follicular fluid. Journal of Endocrinology 188 215-225.

Gould SE, Day M, Jones SS \& Dorai H 2002 BMP-7 regulates chemokine, cytokine, and hemodynamic gene expression in proximal tubule cells1. Kidney International 61 51-60.

Greenwald J, Vega ME, Allendorph GP, Fischer WH, Vale W \& Choe S 2004 A flexible activin explains the membrane-dependent cooperative assembly of TGF-beta family receptors. Molecular Cell 15 485-489.

Gregory SJ \& Kaiser UB 2004 Regulation of gonadotropins by inhibin and activin. Seminars in Reproductive Medicine 22 253-267.

Gregory SJ, Lacza CT, Detz AA, Xu S, Petrillo LA \& Kaiser UB 2004 Synergy between activin A and GnRH in transcriptional activation of the rat follicle-stimulating hormone beta (FSH $\beta$ ) gene. Molecular Endocrinology 19 237-254.

Griffith DL, Keck PC, Sampath TK, Rueger DC \& Carlson WD 1996 Threedimensional structure of recombinant human osteogenic protein 1: structural paradigm for the transforming growth factor beta superfamily. PNAS 93 878-883.

Guo Q, Kumar TR, Woodruff TW, Hadsell LA, DeMayo FJ \& Matzuk MM 1998 Overexpression of mouse follistatin causes reproductive defects in transgenic mice. Molecular Endocrinology 12 96-106.

Hagen M, Fagan K, Steudel W, Carr M, Lane K, Rodman DM \& West J 2007 Interaction of interleukin-6 and the BMP pathway in pulmonary smooth muscle. American Journal of Physiology. Lung Cellular and Molecular Physiology 292 L1473-L1479.

Hay DC, Fletcher J, Payne C, Terrace JD, Gallagher RC, Snoeys J, Black JR, Wojtacha D, Samuel K, Hannoun Z et al. 2008 Highly efficient differentiation of hESCs to functional hepatic endoderm requires activin $\mathrm{A}$ and Wnt3a signaling. PNAS 105 12301-12306.

Hinck AP, Archer SJ, Qian SW, Roberts AB, Sporn MB, Weatherbee JA, Tsang MLS, Lucas R, Zhang BL, Wenker J et al. 1996 Transforming growth factor beta 1: three-dimensional structure in solution and comparison with the X-ray structure of transforming growth factor beta 2. Biochemistry 35 8517-8534.

Hubner G, Hu Q, Smola H \& Werner S 1996 Strong induction of activin expression after injury suggests an important role of activin in wound repair. Developmental Biology 173 490-498.

Hubner G, Alzheimer C \& Werner S 1999 Activin: a novel player in tissue repair processes. Histology and Histopathology 14 295-304.

Jafary H, Larijani B, Farrokhi A, Pirouz M, Mollamohammadi S \& Baharvand H 2008 Differential effect of activin on mouse embryonic stem cell differentiation in insulin-secreting cells under nestin-positive selection and spontaneous differentiation protocols. Cell Biology International 32 278-286.

James D, Levine AJ, Besser D \& Hemmati-Brivanlou A 2005 TGFbeta/ activin/nodal signaling is necessary for the maintenance of pluripotency in human embryonic stem cells. Development 132 1273-1282.

Jiang J, Au M, Lu K, Eshpeter A, Korbutt G, Fisk G \& Majumdar AS 2007 Generation of insulin-producing islet-like clusters from human embryonic stem cells. Stem Cells 25 1940-1953.

Jones KL, de Kretser DM, Clarke IJ, Scheerlinck JP \& Phillips DJ 2004a Characterisation of the rapid release of activin A following acute lipopolysaccharide challenge in the ewe. Journal of Endocrinology 182 69-80.

Jones KL, Kretser DM, Patella S \& Phillips DJ 2004b Activin A and follistatin in systemic inflammation. Molecular and Cellular Endocrinology 225 119-125.

Jones KL, Mansell A, Patella S, Scott BJ, Hedger MP, de Kretser DM \& Phillips DJ 2007 Activin A is a critical component of the inflammatory response, and its binding protein, follistatin, reduces mortality in endotoxemia. PNAS 104 16239-16244.

Jorgez CJ, Klysik M, Jamin SP, Behringer RR \& Matzuk MM 2003 Granulosa cell-specific inactivation of follistatin causes female fertility defects. Molecular Endocrinology 18 953-967.

Kaitu'u-Lino TJ, Phillips DJ, Morison NB \& Salamonsen LA 2008 A new role for activin in endometrial repair after menses. Endocrinology (in press: DOI 10.1210/en.2008-0738). 
Kelber JA, Shani G, Booker EC, Vale WW \& Gray PC 2008 Cripto is a noncompetitive activin antagonist that forms analogous signaling complexes with activin and nodal. Journal of Biological Chemistry 283 4490-4500.

Keutmann HT, Schneyer AL \& Sidis Y 2004 The role of follistatin domains in follistatin biological action. Molecular Endocrinology 18 228-240.

Kipp JL, Kilen SM, Woodruff TK \& Mayo KE 2007 Activin regulates estrogen receptor gene expression in the mouse ovary. Journal of Biological Chemistry $28236755-36765$.

Kitamura R, Takahashi T, Nakajima N, Isodono K, Asada S, Ueno H, Ueyama T, Yoshikawa T, Matsubara H \& Oh H 2007 Stage-specific role of endogenous Smad2 activation in cardiomyogenesis of embryonic stem cells. Circulation Research 101 78-87.

Kumar M, Jordan N, Melton D \& Grapin-Botton A 2003 Signals from lateral plate mesoderm instruct endoderm toward a pancreatic fate. Developmental Biology 259 109-122.

Lamba P, Santos MM, Philips DP \& Bernard DJ 2006 Acute regulation of murine follicle-stimulating hormone beta subunit transcription by activin $\mathrm{A}$. Journal of Molecular Endocrinology 36 201-220.

Lamba P, Khivansara V, D’Alessio AC, Santos MM \& Bernard DJ 2008 Pairedlike homeodomain transcription factors 1 and 2 regulate follicle-stimulating hormone beta-subunit transcription through a conserved cis-element. Endocrinology 149 3095-3108.

Lara-Pezzi E, Felkin LE, Birks EJ, Sarathchandra P, Panse KD, George R, Hall JL, Yacoub MH, Rosenthal N \& Barton PJR 2008 Expression offollistatin-related genes is altered in heart failure. Endocrinology 149 5822-5827.

Lee MJ, Yang CW, Jin DC, Chang YS, Bang BK \& Kim YS 2003 Bone morphogenetic protein-7 inhibits constitutive and interleukin- $1 \beta$-induced monocyte chemoattractant protein-1 expression in human mesangial cells: role for JNK/AP-1 pathway. Journal of Immunology $1702557-2563$.

Li L, Yi Z, Seno M \& Kojima I 2004 Activin A and betacellulin: effect on regeneration of pancreatic beta-cells in neonatal streptozotocin-treated rats. Diabetes $\mathbf{5 3}$ 608-615.

Lin SY, Craythorn RG, O'Connor AE, Matzuk MM, Girling JE, Morrison JR $\&$ de Kretser DM 2008 Female infertility and disrupted angiogenesis are actions of specific follistatin isoforms. Molecular Endocrinology 22 415-429.

Mamin A \& Philippe J 2006 Activin A decreases glucagon and arx gene expression in $\alpha$ cell lines. Molecular Endocrinology 21 259-273.

Martins da Silva SJ, Bayne RA, Cambray N, Hartley PS, McNeilly AS \& Anderson RA 2004 Expression of activin subunits and receptors in the developing human ovary: activin A promotes germ cell survival and proliferation before primordial follicle formation. Developmental Biology 266 334-345.

Mather JP, Attie KM, Woodruff TK, Rice GC \& Phillips DM 1990 Activin stimulates spermatogonial proliferation in germ-Sertoli cell cocultures from immature rat testis. Endocrinology 127 3206-3214.

Mather JP, Woodruff TK \& Krummen LA 1992 Paracrine regulation of reproductive function by inhibin and activin. Proceedings of the Society for Experimental Biology and Medicine 201 1-15.

Mather JP, Moore A \& Li RH 1997 Activins, inhibins, and follistatins: further thoughts on a growing family of regulators. Proceedings of the Society for Experimental Biology and Medicine 215 209-222.

Mathews LS \& Vale WW 1993 Molecular and functional characterization of activin receptors. Receptor 3 173-181.

Matzuk MM, Kumar TR \& Bradley A 1995a Different phenotypes for mice deficient in either activins or activin receptor type II. Nature 374 356-360.

Matzuk MM, Kumar TR, Vassilli A, Bickenbach RR, Roop DR, Jaenisch R \& Bradley A 1995b Functional analysis of activins during mammalian development. Nature 374 354-356.

Matzuk MM, Lu N, Vogel HJ, Sellheyer K, Roop DR \& Bradley A 1995 c Multiple defects and perinatal death in mice deficient in follistatin. Nature 374 360-363

McGillivray SM, Thackray VG, Coss D \& Mellon PL 2007 Activin and glucocorticoids synergistically activate follicle-stimulating hormone betasubunit gene expression in the immortalized LbetaT2 gonadotrope cell line. Endocrinology 148 762-773.

Menke DB \& Page DC 2002 Sexually dimorphic gene expression in the developing mouse gonad. Gene Expression Patterns 2 359-367.
Mfopou JK \& Bouwens L 2008 Hedgehog signals in pancreatic differentiation from embryonic stem cells: revisiting the neglected. Differentiation 76 107-117.

Mfopou JK, De GV, Xu X, Heimberg H \& Bouwens L 2007 Sonic hedgehog and other soluble factors from differentiating embryoid bodies inhibit pancreas development. Stem Cells 25 1156-1165.

Michel U, Ebert S, Phillips D \& Nau R 2003a Serum concentrations of activin and follistatin are elevated and run in parallel in patients with septicemia. European Journal of Endocrinology 148 559-564.

Michel U, Gerber J, E O'Connor A, Bunkowski S, Bruck W, Nau R \& Phillips DJ $2003 b$ Increased activin levels in cerebrospinal fluid of rabbits with bacterial meningitis are associated with activation of microglia. Journal of Neurochemistry 86 238-245.

Mukherjee A, Sidis Y, Mahan A, Raher MJ, Xia Y, Rosen ED, Bloch KD, Thomas MK \& Schneyer AL 2007 FSTL3 deletion reveals roles for TGFbeta family ligands in glucose and fat homeostasis in adults. PNAS 104 1348-1353.

Myers M, Gay E, McNeilly AS, Fraser HM \& Duncan WC 2007 In vitro evidence suggests activin-A may promote tissue remodeling associated with human luteolysis. Endocrinology 148 3730-3739.

Myers M, van den Driesche S, McNeilly AS \& Duncan WC 2008 Activin A reduces luteinisation of human luteinised granulosa cells and has opposing effects to human chorionic gonadotropin in vitro. Journal of Endocrinology 199 201-212.

Nostro MC, Cheng X, Keller GM \& Gadue P 2008 Wnt, activin, and BMP signaling regulate distinct stages in the developmental pathway from embryonic stem cells to blood. Cell Stem Cell 2 60-71.

Ogawa K, Abe K, Kurosawa N, Kurohmaru M, Sugino H, Takahashi M \& Hayashi Y 1993 Expression of alpha, beta A and beta B subunits of inhibin or activin and follistatin in rat pancreatic islets. FEBS Letters 319 217-220.

Ogawa T, Yogo K, Ishida N \& Takeya T 2003 Synergistic effects of activin and FSH on hyperphosphorylation of $\mathrm{Rb}$ and $\mathrm{G} 1 / \mathrm{S}$ transition in rat primary granulosa cells. Molecular and Cellular Endocrinology 210 31-38.

Ogawa K, Funaba M, Chen Y \& Tsujimoto M 2006 Activin A functions as a Th2 cytokine in the promotion of the alternative activation of macrophages. Journal of Immunology 177 6787-6794.

Ogawa K, Saito A, Matsui H, Suzuki H, Ohtsuka S, Shimosato D, Morishita Y, Watabe T, Niwa H \& Miyazono K 2007 Activin-nodal signaling is involved in propagation of mouse embryonic stem cells. Journal of Cell Science 120 55-65.

Ogawa K, Funaba M \& Tsujimoto M 2008 A dual role of activin A in regulating immunoglobulin production of B cells. Journal of Leukocyte Biology 83 1451-1458.

Okuma Y, Saito K, O'Connor AE, Phillips DJ, de Kretser DM \& Hedger MP 2005 Reciprocal regulation of activin A and inhibin B by interleukin-1 (IL-1) and follicle-stimulating hormone (FSH) in rat Sertoli cells in vitro. Journal of Endocrinology 185 99-110.

Onichtchouk D, Chen YG, Dosch R, Gawantka V, Delius H, Massague J \& Niehrs C 1999 Silencing of TGF-beta signalling by the pseudoreceptor BAMBI. Nature 401 480-485.

Ota F, Maeshima A, Yamashita S, Ikeuchi H, Kaneko Y, Kuroiwa T, Hiromura K, Ueki K, Kojima I \& Nojima Y 2003 Activin A induces cell proliferation of fibroblast-like synoviocytes in rheumatoid arthritis. Arthritis and Rheumatism 48 2442-2449.

Pangas SA, Jorgez CJ, Tran M, Agno J, Li X, Brown CW, Kumar TR \& Matzuk MM 2007 Intraovarian activins are required for female fertility. Molecular Endocrinology 21 2458-2471.

Park Y, Maizels ET, Feiger ZJ, Alam H, Peters CA, Woodruff TK, Unterman TG, Lee EJ, Jameson JL \& Hunzicker-Dunn M 2005 Induction of cyclin D2 in rat granulosa cells requires FSH-dependent relief from FOXO1 repression coupled with positive signals from Smad. Journal of Biological Chemistry 280 9135-9148.

Park MK, Han C, Lee KH, Hong SH, Kim HS, Lee YJ, Jeong IK, Noh JH, Yang TY, Lee MS et al. 2007 Effects of activin A on pancreatic ductal cells in streptozotocin-induced diabetic rats. Transplantation $\mathbf{8 3}$ 925-930. 
Pearson S, Sroczynska P, Lacaud G \& Kouskoff V 2008 The stepwise specification of embryonic stem cells to hematopoietic fate is driven by sequential exposure to Bmp4, activin A, bFGF and VEGF. Development 135 $1525-1535$.

Phillips BW, Hentze H, Rust WL, Chen QP, Chipperfield H, Tan EK, Abraham S, Sadasivam A, Soong PL, Wang ST et al. 2007 Directed differentiation of human embryonic stem cells into the pancreatic endocrine lineage. Stem Cells and Development 16 561-578.

Riccioli A, Starace D, Galli R, Fuso A, Scarpa S, Palombi F, De Cesaris P, Ziparo E \& Filippini A 2006 Sertoli cells initiate testicular innate immune responses through TLR activation. Journal of Immunology 177 7122-7130.

Robson NC, Phillips DJ, McAlpine T, Shin A, Svobodova S, Toy T, Pillay V, Kirkpatrick N, Zanker D, Wilson K et al. 2008 Activin-A: a novel dendritic cell-derived cytokine that potently attenuates CD40 ligand-specific cytokine and chemokine production. Blood 111 2733-2743.

Saito S, Sidis Y, Mukherjee A, Xia Y \& Schneyer A 2005 Differential biosynthesis and intracellular transport of follistatin isoforms and follistatinlike-3. Endocrinology 146 5052-5062.

Schneyer AL, Rzucidlo DA, Sluss PM \& Crowley WF Jr. 1994 Charactrerization of unique binding kinetics of follistatin and activin or inhbin in serum. Endocrinology 135 667-674.

Schneyer AL, Hall HA, Lambert-Messerlian G, Wang QF, Sluss P \& Crowley WF Jr 1996 Follistatin-activin complexes in human serum and follicular fluid differ immunologically and biochemically. Endocrinology $137240-247$.

Schneyer A, Tortoriello D, Sidis Y, Keutmann H, Matsuzaki T \& Holmes W 2001 Follistatin-related protein (FSRP): a new member of the follistatin gene family. Molecular and Cellular Endocrinology 180 33-38.

Schneyer AL, Wang Q, Sidis Y \& Sluss PM 2004 Differential distribution of follistatin isoforms: application of a new FS315-specific immunoassay. Journal of Clinical Endocrinology and Metabolism 89 5067-5075.

Schneyer AL, Sidis Y, Gulati A, Sun JL, Keutmann H \& Krasney PA 2008 Differential antagonism of activin, myostatin and growth and differentiation factor 11 by wild-type and mutant follistatin. Endocrinology 149 4589-4595.

Shafiee-Kermani F, Han SO \& Miller WL 2007 Chronic gonadotropinreleasing hormone inhibits activin induction of the ovine folliclestimulating hormone beta-subunit: involvement of $3^{\prime}, 5^{\prime}$-cyclic adenosine monophosphate response element binding protein and nitric oxide synthase type I. Endocrinology 148 3346-3355.

Sharpe RM, McKinnell C, Kivlin C \& Fisher JS 2003 Proliferation and functional maturation of Sertoli cells, and their relevance to disorders of testis function in adulthood. Reproduction 125 769-784.

Shi Y, Hou L, Tang F, Jiang W, Wang P, Ding M \& Deng H 2005 Inducing embryonic stem cells to differentiate into pancreatic beta cells by a novel three-step approach with activin A and all-trans retinoic acid. Stem Cells 23 656-662.

Shull MM, Ormsby I, Kier AB, Pawlowski S, Diebold RJ, Yin M, Allen R, Sidman C, Proetzel G, Calvin D et al. 1992 Targeted disruption of the mouse transforming growth factor-beta 1 gene results in multifocal inflammatory disease. Nature 359 693-699.

Sidis Y, Schneyer AL, Sluss PM, Johnson LN \& Keutmann HT 2001 Follistatin: essential role for the N-terminal domain in activin binding and neutralization. Journal of Biological Chemistry 276 17718-17726.

Sidis Y, Tortoriello DV, Holmes WE, Pan Y, Keutmann HT \& Schneyer AL 2002 Follistatin-related protein and follistatin differentially neutralize endogenous vs. exogenous activin. Endocrinology 143 1613-1624.

Sidis Y, Schneyer AL \& Keutmann HT 2005 Heparin and activin-binding determinants in follistatin and FSTL3. Endocrinology 146 130-136.

Sidis Y, Mukherjee A, Keutmann H, Delbaere A, Sadatsuki M \& Schneyer A 2006 Biological activity of follistatin isoforms and follistatin like-3 are dependent on differential cell surface binding and specificity for activin, myostatin and BMP's. Endocrinology 147 3586-3597.

Smart NG, Apelqvist AA, Gu X, Harmon EB, Topper JN, MacDonald RJ \& Kim SK 2006 Conditional expression of Smad7 in pancreatic beta cells disrupts TGF-beta signaling and induces reversible diabetes mellitus. PLoS Biology 4 e39.
Smith C, Yndestad A, Halvorsen B, Ueland T, Waehre T, Otterdal K, Scholz H, Endresen K, Gullestad L, Froland SS et al. 2004 Potential antiinflammatory role of activin A in acute coronary syndromes. Journal of the American College of Cardiology 44 369-375.

Smith JR, Vallier L, Lupo G, Alexander M, Harris WA \& Pedersen RA 2008 Inhibition of activin/nodal signaling promotes specification of human embryonic stem cells into neuroectoderm. Developmental Biology 313 107-117.

Spady TJ, Shayya R, Thackray VG, Ehrensberger L, Bailey JS \& Mellon PL 2004 Androgen regulates follicle-stimulating hormone beta gene expression in an activin-dependent manner in immortalized gonadotropes. Molecular Endocrinology 18 925-940.

Stamler R, Keutmann HT, Sidis Y, Kattamuri C, Schneyer A \& Thompson TB 2008 The structure of FSTL3.activin A complex: differential binding of n-terminal domains influences follistatin-type antagonist specificity. Journal of Biological Chemistry 283 32831-32838.

Sugino K, Kurosawa N, Nakamura T, Takio K, Shimasaki S, Ling N, Titani K \& Sugino H 1993 Molecular heterogeneity of follistatin, an activin-binding protein. Journal of Biological Chemistry 68 15579-15587.

Sugino H, Sugino K, Hashimoto O, Shoji H \& Nakamura T 1997 Follistatin and its role as an activin-binding protein. Journal of Medical Investigation 44 1-14.

Sumi T, Tsuneyoshi N, Nakatsuji N \& Suemori H 2008 Defining early lineage specification of human embryonic stem cells by the orchestrated balance of canonical Wnt/beta-catenin, activin/nodal and BMP signaling. Development 135 2969-2979.

Suszko MI, Lo DJ, Suh H, Camper SA \& Woodruff TK 2003 Regulation of the rat follicle-stimulating hormone $\beta$-subunit promoter by activin. Molecular Endocrinology 17 318-332.

Suszko MI, Balkin DM, Chen Y \& Woodruff TK 2005 Smad3 mediates activin-induced transcription of follicle-stimulating hormone beta-subunit gene. Molecular Endocrinology 19 1849-1858.

Suszko MI, Antenos M, Balkin DM \& Woodruff TK 2008 Smad3 and Pitx2 cooperate in stimulation of FSHbeta gene transcription. Molecular and Cellular Endocrinology 281 27-36.

Thackray VG \& Mellon PL 2008 Synergistic induction of follicle-stimulating hormone beta-subunit gene expression by gonadal steroid hormone receptors and Smad proteins. Endocrinology 149 1091-1102.

Thompson TB, Woodruff TK \& Jardetzky TS 2003 Structures of an ActRIIB:activin A complex reveal a novel binding mode for TGF-beta ligand:receptor interactions. EMBO Journal 22 1555-1566.

Thompson TB, Lerch TF, Cook RW, Woodruff TK \& Jardetzky TS 2005 The structure of the follistatin:activin complex reveals antagonism of both type I and type II receptor binding. Developmental Cell 9 535-543.

Tortoriello DV, Sidis Y, Holtzman DA, Holmes WE \& Schneyer AL 2001 Human follistatin-related protein: a structural homologue of follistatin with nuclear localization. Endocrinology 142 3426-3434.

Totsuka Y, Tabuchi M, Kojima I, Shibai H \& Ogata E 1988 A novel action of activin A: stimulation of insulin secretion in rat pancreatic islets. Biochemical and Biophysical Research Communications 156 335-339.

Tremblay KD, Hoodless PA, Bikoff EK \& Robertson EJ 2000 Formation of the definitive endoderm in mouse is a Smad2-dependent process. Development 127 3079-3090.

Tsuchida K, Nakatani M, Yamakawa N, Hashimoto O, Hasegawa Y \& Sugino H 2004 Activin isoforms signal through type I receptor serine/ threonine kinase ALK7. Molecular and Cellular Endocrinology 220 59-65.

Tsuchida K, Nakatani M, Uezumi A, Murakami T \& Cui X 2008 Signal transduction pathway through activin receptors as a therapeutic target of musculoskeletal diseases and cancer. Endocrine Journal 55 11-21.

Vale W, Rivier C, Hsueh A, Campen C, Meunier H, Bicsak T, Vaughan J, Corrigan A, Bardin W, Sawchenko P et al. 1988 Chemical and biological characterization of the inhibin family of protein hormones. Recent Progress in Hormone Research 44 1-34.

Vallier L, Alexander M \& Pedersen RA 2005 Activin/nodal and FGF pathways cooperate to maintain pluripotency of human embryonic stem cells. Journal of Cell Science 118 4495-4509. 
Vassalli A, Matzuk MM, Gardner HA, Lee KF \& Jaenisch R 1994 Activin/inhibin beta B subunit gene disruption leads to defects in eyelid development and female reproduction. Genes and Development 8 414-427.

Verspohl EJ, Ammon HP \& Wahl MA 1993 Activin A: its effects on rat pancreatic islets and the mechanism of action involved. Life Sciences $\mathbf{5 3}$ 1069-1078.

Wada M, Shintani Y, Kosaka M, Sano T, Hizawa K \& Saito S 1996 Immunohistochemical localization of activin A and follistatin in human tissues. Endocrine Journal 43 375-385.

Wang SY, Tai GX, Zhang PY, Mu DP, Zhang XJ \& Liu ZH 2008a Inhibitory effect of activin A on activation of lipopolysaccharide-stimulated mouse macrophage RAW264.7 cells. Cytokine 42 85-91.

Wang Y, Fortin J, Lamba P, Bonomi M, Persani L, Roberson MS \& Bernard DJ 2008b Activator protein-1 and smad proteins synergistically regulate human follicle-stimulating hormone beta-promoter activity. Endocrinology 149 5577-5591.

Weiss J, Harris PE, Halvorson LM, Crowley WF \& Jameson JL 1992 Dynamic regulation of follicle-stimulating hormone-beta messinger ribonucleic acid levels by activin and gonadotropin-releasing hormone in perifused rat pituitary cells. Endocrinology 131 1403-1408.

Welt C, Sidis Y, Keutmann H \& Schneyer A 2002 Activins, inhibins, and follistatins: from endocrinology to signaling. A paradigm for the new millennium. Experimental Biology and Medicine 227 724-752.

Willems E \& Leyns L 2008 Patterning of mouse embryonic stem cell-derived pan-mesoderm by activin $\mathrm{A} /$ nodal and Bmp4 signaling requires fibroblast growth factor activity. Differentiation 76 745-759.

Wilson KM, Smith AI \& Phillips DJ 2006 Stimulatory effects of lipopolysaccharide on endothelial cell activin and follistatin. Molecular and Cellular Endocrinology 253 30-35.

Wu Z, Zhang W, Chen G, Cheng L, Liao J, Jia N, Gao Y, Dai H, Yuan J, Cheng L et al. 2008 Combinatorial signals of activin/nodal and bone morphogenic protein regulate the early lineage segregation of human embryonic stem cells. Journal of Biological Chemistry 283 24991-25002.

Xia Y, Sidis Y \& Schneyer A 2004 Overexpression of follistatin-like 3 in gonads causes defects in gonadal development and function in transgenic mice. Molecular Endocrinology 18 979-994.

Xia Y, O'Shea T, Almahbobi G \& McFarlane JR 2008a Changes in ovarian follistatin levels during the oestrous cycle in sheep may serve as an intraovarian regulator. Reproduction in Domestic Animals (in press: DOI 10.1016/J.anireprosci.2008.08.022).
Xia Y, O'Shea T \& McFarlane JR $2008 b$ Changes in concentrations of follistatin in maternal plasma and foetal fluids during pregnancy and parturition in sheep. Animal Reproduction Science.

Xiao L, Yuan X \& Sharkis SJ 2006 Activin A maintains self-renewal and regulates FGF, Wnt and BMP pathways in human embryonic stem cells. Stem Cells 28 1476-1480.

Xu RH, Sampsell-Barron TL, Gu F, Root S, Peck RM, Pan G, Yu J, Antosiewicz-Bourget J, Tian S, Stewart R et al. 2008 NANOG is a direct target of TGFbeta/activin-mediated SMAD signaling in human ESCs. Cell Stem Cell 3 196-206.

Yamaoka T, Idehara C, Yano M, Matsushita T, Yamada T, Ii S, Moritani M, Hata J, Sugino H, Noji S et al. 1998 Hypoplasia of pancreatic islets in transgenic mice expressing activin receptor mutants. Journal of Clinical Investigation 102 294-301.

Yao HH, Matzuk MM, Jorgez CJ, Menke DB, Page DC, Swain A \& Capel B 2004 Follistatin operates downstream of Wnt4 in mammalian ovary organogenesis. Developmental Dynamics 230 210-215.

Yao HH-C, Aardema J \& Holthusen K 2006a Sexually dimorphic regulation of inhibin beta $\mathrm{B}$ in establishing gonadal vasculature in mice. Biology of Reproduction 74 978-983.

Yao S, Chen S, Clark J, Hao E, Beattie GM, Hayek A \& Ding S $2006 b$ Longterm self-renewal and directed differentiation of human embryonic stem cells in chemically defined conditions. PNAS 103 6907-6912.

Zhang YQ, Zhang H, Maeshima A, Kurihara H, Miyagawa J, Takeuchi T \& Kojima I 2002 Up-regulation of the expression of activins in the pancreatic duct by reduction of the beta-cell mass. Endocrinology 143 3540-3547.

Zhang XJ, Li Y, Tai GX, Xu GY, Zhang PY, Yang Y, Lao FX \& Liu ZH 2005 Effects of activin $A$ on the activities of the mouse peritoneal macrophages. Cellular \& Molecular Immunology 2 63-67.

Zhang H, Bailey JS, Coss D, Lin B, Tsutsumi R, Lawson MA, Mellon PL \& Webster NJG 2006 Activin modulates the transcriptional response of LssT2 cells to gonadotropin-releasing hormone and alters cellular proliferation. Molecular Endocrinology 20 2909-2930.

\section{Received in final form 13 February 2009 \\ Accepted 2 March 2009}

Made available online as an Accepted Preprint

2 March 2009 